\title{
PODSTAWY STOSOWANIA WYSOKOCIŚNIENIOWEJ STRUGI WODNO-LODOWEJ DO WYDOBYWANIA KONKRECJI POLIMETALICZNYCH Z DNA OCEANU
}

\begin{abstract}
W pracy scharakteryzowano konkrecje polimetaliczne zalegające dno oceaniczne oraz ich zasoby i miejsca występowania, zwłaszcza w przyznanym Polsce obszarze pomiędzy uskokami dna pacyficznego o nazwie Clarion-Clipperton. Zaprezentowano koncepcję zastosowania wysokociśnieniowej strugi wodnej, wspomaganej fizycznym oddziaływaniem granulek suchego lodu $\mathrm{CO}_{2}$, do podmorskiego urobku takich konkrecji. Wskazano na bardzo przydatną cechę zastosowanego lodu, dzięki której jego cząstki nie podlegają zbrylaniu się w środowisku wodnym. Ponadto granulki takiego lodu pod wpływem mechanicznych udarów, występujących w strefie obróbki, ulegają gwałtownej sublimacji. Objętość pęcherzyków fazy gazowej $\mathrm{CO}_{2}$, powstających z częściowego przesublimowania granulek suchego lodu w warunkach panujących na dnie oceanicznym, jest bardzo niewielka. Największe pęcherzyki mają średnice od 1,7 do 2,1 mm. Ich ogromna mnogość sprawia jednak, że strefa robocza staje się obszarem agresywnej erozji, zbliżonej do kawitacji. W artykule tym przedstawiono także podstawy hydropneumatycznego transportu konkrecji polimetalicznych na powierzchnię, określając, na jakiej głębokości należy wtłaczać do rury sprężone powietrze w celu zapewnienia odpowiedniej wydajności tego procesu. Scharakteryzowano także struktury przepływów występujących w różnych przekrojach rury transportowej oraz określono odpowiednie zależności teoretyczne. Przedstawione zależności pozwalają na dokonywanie wyboru najważniejszych parametrów, które decydują o skuteczności opracowanej metody. Przedstawione teoretyczne podstawy odspajania i wydobywania konkrecji polimetalicznych z dna oceanicznego, oparte na wykorzystaniu erozyjnych właściwości wysokociśnieniowej strugi wodno-lodowej $\mathrm{CO}_{2}$ oraz transportowania urobku metodą iniekcji pneumatycznej powinny w istotnym stopniu przyczynić się do zwiększenia skuteczności wydobywania tych konkrecji.
\end{abstract}

Słowa kluczowe: konkrecje polimetaliczne, wysokociśnieniowa struga wodno-lodowa, suchy lód $\mathrm{CO}_{2}$, transport hydropneumatyczny

\footnotetext{
${ }^{1}$ Autor do korespondencji/corresponding author: Przemysław J. Borkowski, Państwowy Instytut Geologiczny - PIB, ul. Rakowiecka 4, 00-975 Warszawa, tel.: 224592515, e-mail: przemyslaw.borkowski@pgi.gov.pl

2 Józef A. Borkowski, Politechnika Koszalińska, e-mail: jozef-borkowski@wp.pl

${ }^{3}$ Mariusz O. Jędrysek, Uniwersytet Wrocławski, e-mail: mariusz.jedrysek@uwr.edu.pl
} 


\section{Wprowadzenie}

Naukowe analizy wykazują, że większość kopalin lądowych wystarczy zaledwie na 50-200 lat, a morza i oceany mogą dostarczyć surowców na wiele tysięcy lat funkcjonowania naszej cywilizacji. Z tego względu u schyłku XX w. wszechocean stał się obszarem intensywnych poszukiwań bogactw mineralnych występujących w postaci osadów dennych i złóż podpowierzchniowych. Olbrzymi rozwój technologii i ogromne nakłady inwestycyjne doprowadziły ostatnio do zintensyfikowania eksploracji i eksploatacji głębin oceanów [10]. Oprócz ropy naftowej i gazu ziemnego szczególnie obiecujące są bogate złoża konkrecji polimetalicznych. Są one najczęściej quasi-kulistymi, nieco spłaszczonymi bułami o rozwiniętej powierzchni. Zwykle posiadają bardzo wysoką zawartość takich metali, jak: mangan, kobalt, miedź, żelazo i nikiel [7]. Jednym z bardziej perspektywicznych obszarów eksploatowania konkrecji jest strefa Clarion-Clipperton, znajdująca się na Pacyfiku (rys. 1).

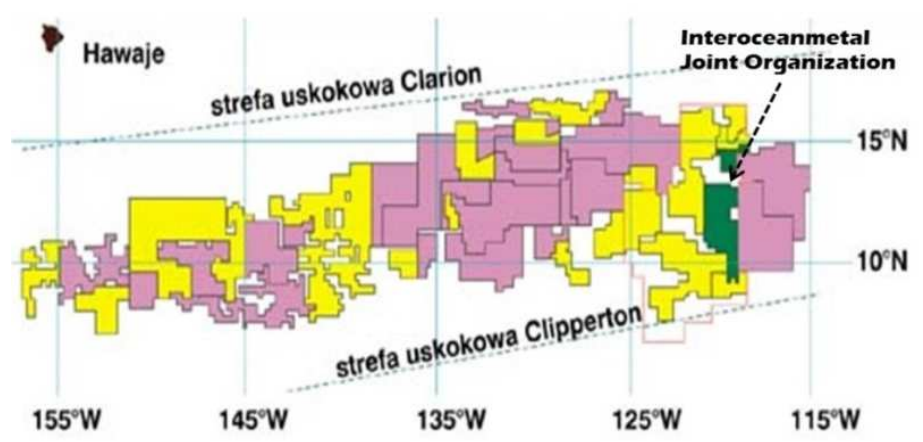

Rys. 1. Mapa lokalizacji pionierskich inwestorów w strefie Clarion-Clipperton

Fig. 1. A map of pioneer's investors localization in Clarion-Clipperton zone

W tej przyrównikowej strefie, obejmującej podmorski uskok denny o głębokości od 4200 do $5200 \mathrm{~m}$, zagęszczenie konkrecji polimetalicznych wynosi powyżej $10 \mathrm{~kg} / \mathrm{m}^{2}$. Od 1992 roku, w ramach organizacji Interoceanmetal Joint Organization, Polska zarządza tam działką o powierzchni $75000 \mathrm{~km}^{2}$ [8]. Szacunkowe zasoby zlokalizowane $\mathrm{w}$ wymienionym obszarze wynoszą prawie $450 \mathrm{mi}$ lionów ton metali, w tym prawie 90 milionów ton manganu, 4 miliony ton niklu, 3,5 miliona ton miedzi i około 0,5 miliona ton kobaltu [6]. Po przeanalizowaniu wszystkich metod przewidzianych do stosowania przy wydobywaniu konkrecji polimetalicznych stwierdzono, że podstawowym problemem każdej z nich jest przede wszystkim transport urobku z dna oceanicznego na pokład statku. Dotyczy to zwłaszcza urabiania tych konkrecji metodami mechanicznymi, które są skomplikowane, a w głębokomorskim transporcie zawodne. 
W niniejszej pracy zaprezentowano koncepcję wydobywania konkrecji polimetalicznych przy użyciu wysokociśnieniowej strugi wodnej z domieszką granulatu suchego lodu $\mathrm{CO}_{2}$, którego cząstki nie podlegają zbrylaniu się w środowisku wodnym. Dzięki ich gwałtownej sublimacji pod wpływem mechanicznych udarów występujących w strefie urobku ułatwiają one odspajanie i pozyskiwanie takich konkrecji.

\section{Hydropneumatyczny sposób transportu konkrecji}

Przeprowadzona analiza stanu zagadnienia wykazała, że dla konkrecji polimetalicznych najbardziej efektywne są metody hydraulicznego transportu urobku na powierzchnię z zastosowaniem iniektora powietrza (rys. 2).

Rys. 2. Idea urabiania i hydraulicznego transportowania konkrecji z użyciem iniektora powietrza

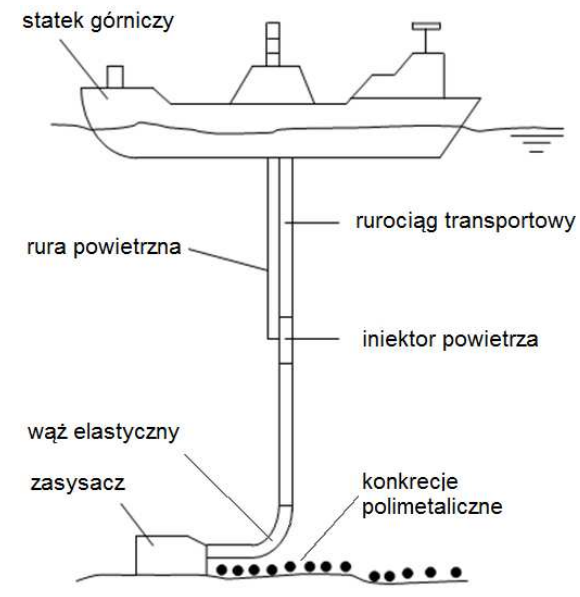
and hydraulic transportation of concretions using air injector

Wprowadzenie sprężonego powietrza do rurociagu transportowego wywołuje określoną intensywność przepływu znajdującej się w nim mieszaniny. Moc niezbędna do jej przepływu zależy od ilości podawanego powietrza oraz głębokości zamocowania iniektora na rurociągu transportowym. Z uwagi na różną gęstość zewnętrznej wody morskiej względem wielofazowej mieszanki znajdującej się wewnątrz rurociągu oraz wyporu i rozszerzalności sprężonego powietrza, konkrecje polimetaliczne zasysane $\mathrm{z}$ dna oceanu są transportowane na jego powierzchnię.

Taki rodzaj transportu hydraulicznego wykazuje wiele zalet, gdyż zapewnia dużą wydajność przy stosunkowo małym zapotrzebowaniu mocy, przez co jest skuteczniejszy i tańszy od mechanicznego. Z podanych względów obecnie poważnie rozważa się budowę statków górniczych wyposażonych w taki rodzaj transportu. Zaletą transportu hydraulicznego jest również to, że przy mokrym wzbogacaniu urobku odpada konieczność instalowania specjalnych pomp [11] w celu wytwarzania zawiesiny flotacyjnej. Ponadto układ hydraulicznego trans- 
portu jest prostszy niż inne rozwiązania mechaniczne. Elastyczna budowa rurowego przewodu łączącego przydenny obszar urabiania konkrecji ze statkiem zapewnia stosunkowo małą wrażliwość na oddziaływanie fal.

Obok zalet, transport hydrauliczny ma również wady wynikające z wysokiej energochłonności wynoszenia konkrecji o większych wymiarach i ograniczonej możliwości wybierania warstwy konkrecji o niewielkiej miąższości.

\section{Hydrostrumieniowy sposób urobku konkrecji}

Doskonalenie metod urabiania konkrecji polimetalicznych i ich transportu hydraulicznego powinno mieć na celu nie tylko zwiększenie hydrodynamicznego oddziaływania cieczy w rurociągach na ruch transportowanych konkrecji, ale i odpowiednią modernizację wszystkich jej elementów składowych. W takich warunkach nieodzowna staje się potrzeba odpowiedniego zintensyfikowania możliwości odspajania konkrecji od podłoża przez zastosowanie odpowiednio skonstruowanego układu roboczo-zasysającego i efektywnego transportowania uzyskanego urobku na pokład statku górniczego. Dlatego też opracowano koncepcję zastosowania wysokociśnieniowej strugi wodnej wspomaganej fizycznym oddziaływaniem cząstek suchego lodu $\mathrm{CO}_{2}$. Uwzględniono przy tym bardzo przydatne cechy tego lodu, dzięki którym jego granulki nie podlegają zbrylaniu w środowisku wodnym. Ponadto, w strefie roboczej, przy dynamicznym udarze część ich objętości ulega sublimacji [3], wytwarzając przy tym dodatkowe spiętrzenia ciśnienia w licznych mikrostrefach. One z kolei wywołują lokalne zaburzenia o charakterze przepływów naddźwiękowych, przez co zachowanie i erozyjność takiej wodno-lodowej strugi roboczej powinna być zbliżona do strugi kawitacyjnej. Pierwszym podzespołem wspomnianego systemu jest głowica robocza umożliwiająca pozyskiwanie i zasysanie konkrecji polimetalicznych. Takie urządzenie zasysające należy, oprócz specjalnych pomp [11], wyposażyć w system odpowiednich tryskaczy (rys. 3), umożliwiający wytwarzanie wysokociśnieniowej strugi wodnej zasilanej granulatem suchego lodu $\mathrm{CO}_{2}$.

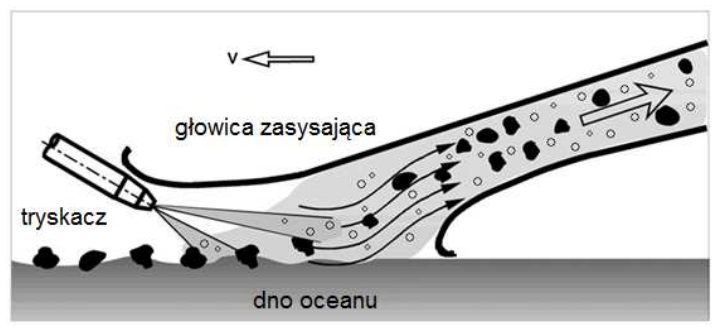

Rys. 3. Koncepcja nowego systemu roboczego do zasysania konkrecji polimetalicznych

Fig. 3. The conception of a new working system (aspirator head) of polymetallic concretions sucking

Korzystne efekty z zastosowania takiej strugi wodno-lodowej potwierdzają również wcześniejsze badania [1], z których wynika, że tego rodzaju struga wysokociśnieniowa wykazuje się kilkakrotnie większą erozyjnością w porównaniu ze strugą wodną o analogicznym ciśnieniu. Wprowadzenie suchego lodu $\mathrm{CO}_{2}$ jako 
dodatku do wysokociśnieniowej strugi wodnej tworzy z niej zatem elastyczne narzędzie wydobywcze, które powinno być bardzo przydatne do stosowania, zwłaszcza w górnictwie podmorskim.

\section{Intensywność sublimacji cząstek suchego lodu $\mathrm{CO}_{2}$}

$\mathrm{Z}$ podanych względów nieodzowne stało się zbadanie przebiegu zjawiska sublimacji granulek suchego lodu $\mathrm{CO}_{2}$, występującego zwłaszcza podczas ich dynamicznej kolizji. Uwzględniając zatem specyficzny charakter plastycznego uderzenia cząstek suchego lodu $\mathrm{CO}_{2}$ o powierzchnię erodowanego materiału, można przyjąć, że energia kinetyczna takiej granulki jest w całości przekształcana w energię sublimacji lodu. Dzięki temu można określić, jaka część granulki suchego lodu ulega przesublimowaniu podczas takiego uderzenia. Opisuje to następująca zależność [3]:

$$
z=\frac{E_{k}}{c_{s} m_{i}}
$$

Na podstawie szczegółowych analiz określono [3], że w zależności od ciśnienia strugi wodnej oddziałującej w takich warunkach, sublimacji podlega przeciętnie 1,4-7,3\% objętości granulki suchego lodu $\mathrm{CO}_{2}$, co świadczy o ograniczonym obszarze występowania tego zjawiska. Wykorzystując prawo Boile'a, określono objętość fazy gazowej powstającej z przesublimowania takiej ilości lodu $\mathrm{CO}_{2}$ w warunkach znacznego ciśnienia, wywieranego przez otaczającą wodę morską. Wspomnianą objętość gazu opisuje następująca zależność [3]:

$$
V_{g}=\frac{V E_{k} p_{a}}{c_{s} m p_{m}} \delta \cdot w
$$

Wyniki obliczeń dokonanych na podstawie zależności (2), określonej zasadami fizyki klasycznej, z uwzględnieniem nadciśnienia $(\Delta p)$ ponad wartość ciśnienia otoczenia panującego na dnie oceanicznym, przedstawiono na rys. 4. Warunki fizyczne występujące na dnie oceanu znacznie odbiegają od normalnych, przez co rzeczywista objętość generowanego gazu $\mathrm{CO}_{2}$ jest stosunkowo mała. Nie można jednak bez badań eksperymentalnych określić dynamicznych efektów występujących w takich warunkach. Eksperymenty te są możliwe do przeprowadzenia na dnie oceanicznym bez większych problemów technicznych, ponieważ można zastosować strugę wodno-lodową $\mathrm{CO}_{2}$ o jej roboczym nadciśnieniu wielokrotnie wyższym niż ciśnienie otaczającej wody morskiej.

Z przytoczonych danych wynika jednoznacznie, że objętość pęcherzyków fazy gazowej $\mathrm{CO}_{2}$, wysublimowanej z granulek suchego lodu w warunkach panujących na dnie oceanicznym (odpowiadającym strefie Clarion-Clipperton), nawet przy zastosowaniu strugi wodno-lodowej $\mathrm{CO}_{2}$ o najwyższych wartościach ciśnie- 


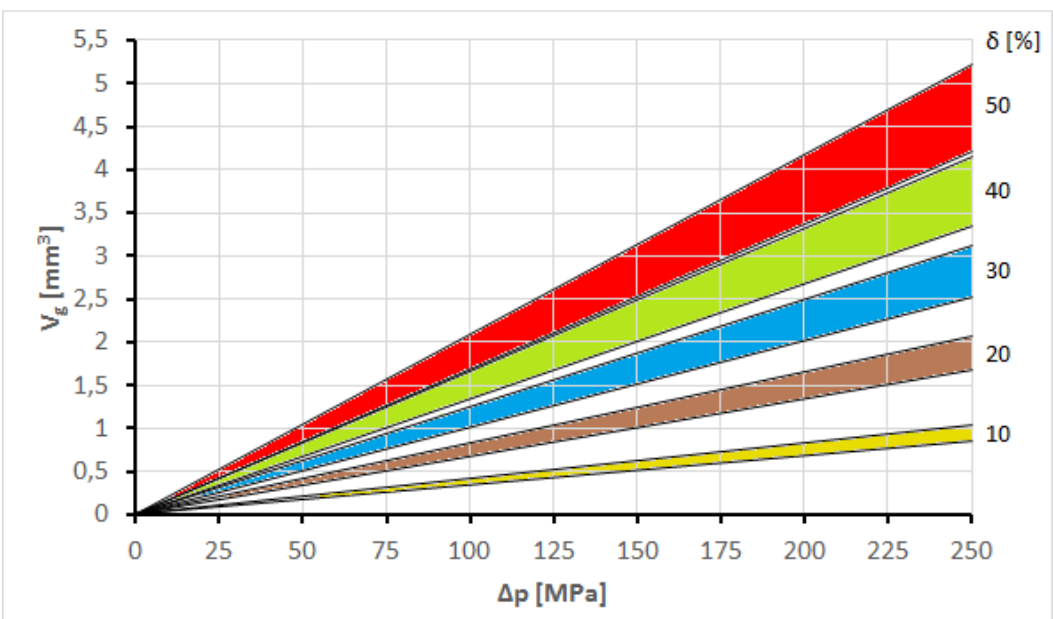

Rys. 4. Zależność objętości gazu $\mathrm{CO}_{2}$ powstałego z sublimacji granulki suchego lodu od nadciśnienia $\Delta p$ strugi wodnej względem ciśnienia otaczającego i efektywności sublimacji lodu

Fig. 4. $\mathrm{CO}_{2}$ gas volume of sublimated dry ice pellet vs. water jet overpressure $\Delta p$ in relation to ambient pressure and effectiveness of ice sublimation

nia jest bardzo niewielka. W takich warunkach ciśnienia wody morskiej nawet te największe kuliste pęcherzyki mają średnice zawierające się w zakresie od 1,7 do 2,1 mm. Oddziaływanie każdego takiego indywidualnego pęcherzyka należy zatem rozpatrywać wyłącznie jako lokalne i ograniczone, jednak ze względu na ich ogromną mnogość strefa robocza staje się obszarem agresywnej erozji, odpowiadającej erozyjności strugi kawitacyjnej.

\section{Teoretyczne podstawy wydobywania konkrecji}

Dzięki efektowi sublimacji częściowej objętości granulek suchego lodu powstaje w rurociągu znikoma ilość fazy gazowej $\mathrm{CO}_{2}$, stanowiąca wręcz niezauważalną część trójfazowej mieszaniny: gaz $\mathrm{CO}_{2}+$ woda + konkrecje polimetaliczne. Powstająca w głowicy zasysającej nieznaczna ilość fazy gazowej $\mathrm{CO}_{2}$ nie ma właściwie wpływu na podnoszenie wspomnianej mieszaniny [2]. W celu zapewnienia efektywnego transportu konkrecji na powierzchnię należy zatem wprowadzić do wnętrza rurociągu transportowego odpowiednią ilość sprężonego powietrza. Wymaga to zainstalowania na rurociągu iniektora powietrza o odpowiedniej wydajności, usytuowanego na określonej głębokości. Model takiej metody wydobywczej, uproszczony do celów teoretycznych, przedstawiono na rys. 5 . 


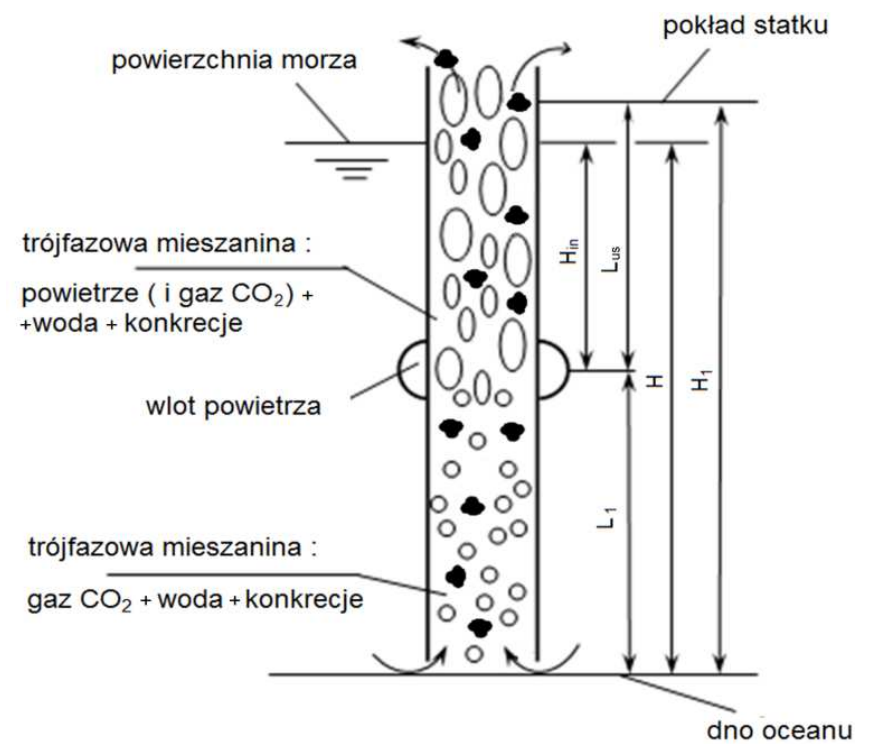

Rys. 5. Hydropneumatyczny (z gazem $\mathrm{CO}_{2}$ ) model transportu konkrecji polimetalicznych

Fig. 5. Hydro-pneumatic $\mathrm{CO}_{2}$-based model of transportation of polymetallic concretions

Wydajność zmodyfikowanego transportu hydropneumatycznego zależy głównie od wydatku podawanego powietrza oraz głębokości zamocowania iniektora na rurociągu transportowym. W celu świadomego sterowania efektywnością takiego transportu należy dokonywać odpowiedniego wyboru analizowanych tutaj najważniejszych parametrów. W rzeczywistości trójfazowy przepływ gaz-ciecz-ciało stałe pod względem fizycznym można rozpatrywać jako przepływ dwufazowych ośrodków ciągłych (powietrza i wody morskiej) z wtrąceniami ciał stałych, tj. konkrecji polimetalicznych. Zwykle też model takiego przepływu dwufazowego (gazowo-cieczowego) charakteryzuje się strukturą pęcherzyków rozproszonych w wodzie. Taki model zastosowano również do analizy transportu buł metalicznych. Istotną cechę fizyczną konkrecji polimetalicznej, jaką jest swobodna prędkość osiadania $\left(v_{s o}\right)$ w wodzie, można określić drogą eksperymentalną. Prędkość taką wyraża następujące równanie empiryczne [9]:

$$
v_{s o}=2,754 \cdot \sqrt{g d_{s}\left(\frac{\rho_{s}}{\rho_{l}}-1\right)}
$$

Do zainicjowania transportu konkrecji wymagane jest dynamiczne jej poderwanie, dlatego średnia prędkość przepływu wody w rurociągu musi być przynajmniej dwukrotnie większa niż prędkość swobodnego osiadania konkrecji. Im 
większa jednak jest ta prędkość, tym wskutek zwiększonego tarcia występuje większy spadek ciśnienia. Zazwyczaj przyjmuje się wartość dwukrotnie większą od $v_{s o}$ [5]. Jest to słuszne zarówno dla przepływu dwufazowego, jak i trójfazowego, przy czym dla rozpatrywanego układu dwufazowego musi być spełniony następujący warunek [12]:

$$
v_{l 2}=v_{m 2}+c_{s p} v_{s o}
$$

Występująca tu prędkość przepływu mieszaniny dwufazowej $\left(v_{m 2}\right)$ może być określona według następującego równania empirycznego:

$$
v_{m 2}=1471,65 \frac{P}{c_{t} \rho_{s} D^{2} T}
$$

W rurowym układzie transportu hydropneumatycznego całkowity spadek ciśnienia w przepływie mieszaniny trójfazowej jest spowodowany stratami: grawitacyjnymi, tarciem i koniecznością przyspieszania przepływu takiego urobku [4]. Uwzględniając takie straty, określono następującą empiryczną zależność, opisującą prędkość przepływu pęcherzy powietrznych $\left(v_{b 3}\right)$ [12]:

$$
v_{b 3}=\frac{1,2 \cdot\left(Q_{s}+Q_{l}+Q_{g o}\right)}{A}+0,35 \sqrt{g D}
$$

Wydajność pionowego przemieszczania konkrecji polimetalicznych zależy od ilości sprężonego powietrza wtłaczanego do rury transportowej na określonej głębokości. Minimalną głębokość zainstalowania odpowiedniego iniektora, umożliwiającego efektywne wtłaczanie powietrza do tego rurociągu, można określić według następującej zależności empirycznej [12]:

$$
H_{i n}=H\left(1-\frac{\rho_{l}}{\rho_{m 2}} \frac{2 g D}{2 g D+\lambda_{m} v_{l 2}^{2}}\right)+\frac{D v_{l 2}^{2}}{\rho_{m 2} g\left(2 g D+\lambda_{m} v_{l 2}^{2}\right)}
$$

Zapotrzebowanie energii, zużywanej do zapewnienia ciągłości hydropneumatycznego transportu wydobywanych konkrecji polimetalicznych opisuje następujące równanie [12]:

$$
N_{1}=Q_{s}\left(\rho_{s}-\rho_{l}\right) g\left(H_{s}+L_{s}\right)+\rho_{s} g\left(L-H_{s}\right)
$$

Z kolei zużycie energii na wytworzenie sprężonego powietrza:

$$
N_{2}=p_{a} Q_{g o} \ln \frac{p_{t}}{p_{a}}
$$


Sprawność hydropneumatycznego transportu konkrecji jest zatem równa:

$$
\eta=\frac{N_{1}}{N_{2}}=\frac{Q_{s}\left(\rho_{s}-\rho_{l}\right) g\left(H_{s}+L_{s}\right)+\rho_{s} g\left(L-H_{s}\right)}{p_{a} Q_{g o} \ln \frac{p_{t}}{p_{a}}}
$$

Powyższe, jedynie skrótowo zasygnalizowane analizy wybranych zagadnień wykazały, że hydropneumatyczna metoda transportu zapewni skuteczne wydobywanie konkrecji polimetalicznych z dna oceanicznego o głębokości i warunkach występujących w strefie Clarion-Clipperton.

\section{Podsumowanie}

Przeprowadzone analizy procesowe umożliwiły opracowanie oryginalnej metody wydobywania konkrecji polimetalicznych, wykorzystującej wysokociśnieniową strugę wodno-lodową $\mathrm{CO}_{2}$. W wyniku zastosowanej analityki systemowej, uwzględniającej głównie struktury przepływów występujących w różnych przekrojach rury transportującej urobek, opracowano podstawy transportu metodą hydropneumatyczną. Wszystkie istotne zagadnienia zostały opisane odpowiednimi równaniami i wzorami empirycznymi, umożliwiającymi określenie najważniejszych parametrów decydujących o skuteczności opracowanej metody. Ich analiza wykazała, że wydajność takiej metody urobku konkrecji polimetalicznych silnie zależy od wydatku zastosowanej strugi wodno-lodowej, natomiast zintensyfikowanie ich pionowego transportu jest uwarunkowane przede wszystkim wydatkiem sprężonego powietrza, wtryskiwanego do rury transportowej na ściśle określonej głębokości.

\section{Oznaczenia}

$c_{s}$ - ciepło właściwe i sublimacji lodu $\mathrm{CO}_{2}[\mathrm{~J} / \mathrm{g}]$,

$c_{s p}$ - przestrzenna koncentracja konkrecji,

$c_{t}$ - koncentracja konkrecji przeznaczonych do transportu,

$d_{s}$ - przeciętna średnica konkrecji obliczana na podstawie jej masy [m],

$g \quad-$ przyspieszenie ziemskie $\left[\mathrm{m} / \mathrm{s}^{2}\right]$,

$m$ - masa granulki lodu $\mathrm{CO}_{2}[\mathrm{~g}]$,

$p_{a}$ - ciśnienie atmosferyczne $[\mathrm{Pa}]$,

$p_{m}$ - ciśnienie otoczenia na dnie oceanu $[\mathrm{Pa}]$,

$p_{t}$ - ciśnienie wytworzone sprężonego powietrza [Pa],

$\Delta p$ - nadciśnienie strugi wodnej względem ciśnienia wody otaczającej na dnie oceanu $[\mathrm{Pa}]$,

$v_{b 3}$ - prędkość przepływu pęcherzyków powietrza w mieszaninie trójfazowej $[\mathrm{m} / \mathrm{s}]$,

$v_{l 2}$ - prędkość przepływu wody i unoszenia urobku w dolnej części rury transportowej $[\mathrm{m} / \mathrm{s}]$,

$v_{m 2}$ - prędkość przepływu dwufazowej mieszaniny w rurze transportowej $[\mathrm{m} / \mathrm{s}]$,

$v_{s o}$ - prędkość osiadania konkrecji w wodzie $[\mathrm{m} / \mathrm{s}]$, 
w - współczynnik zwiększenia objętości fazy gazowej $\mathrm{CO}_{2}$,

$z$ - przesublimowana część objętości granulki suchego lodu $\mathrm{CO}_{2}$,

$\delta$ - efektywność sublimacji lodu $\mathrm{CO}_{2}$,

$\rho_{l}-$ gęstość wody morskiej $\left[\mathrm{kg} / \mathrm{m}^{3}\right]$

$\rho_{m 2}$ - gęstość urobku przepływającego w dolnej części rury transportowej $\left[\mathrm{kg} / \mathrm{m}^{3}\right]$,

$\rho_{s}-$ gęstość konkrecji $\left[\mathrm{kg} / \mathrm{m}^{3}\right]$,

$\lambda_{m}$ - współczynnik tarcia urobku przepływającego w rurze transportowej,

$D$ - wewnętrzna średnica rury transportowej [m],

$E_{k}$ - energia kinetyczna cząstek suchego lodu $\mathrm{CO}_{2}[\mathrm{~J}]$,

$H$ - głębokość dna morskiego w miejscu pozyskiwania konkrecji [m],

$H_{\text {in }}$ - głębokość zamontowania wtryskiwacza powietrza [m],

$L$ - długość przewodu transportowego [m],

$L_{s}$ - długość sztywnego przewodu transportowego [m],

$N_{1}$ - zapotrzebowanie energii do transportu hydropneumatycznego [W],

$N_{2}$ - zapotrzebowanie energii na wytworzenie sprężonego powietrza [W],

$P$ - roczna produkcja konkrecji [t],

$Q_{g o}$ - objętościowy wydatek powietrza przepływającego przez rurociąg transportowy $\left[\mathrm{m}^{3} / \mathrm{s}\right]$,

$Q_{l}$ - objętościowy wydatek wody przepływającej przez rurociąg transportowy $\left[\mathrm{m}^{3} / \mathrm{s}\right]$,

$Q_{s}$ - objętościowy wydatek konkrecji przepływających przez rurociąg transportowy $\left[\mathrm{m}^{3} / \mathrm{s}\right]$,

$T$ - roczna liczba dni roboczych,

$V_{g}$ - objętość gazu $\mathrm{CO}_{2}$ procesu sublimacji $\left[\mathrm{mm}^{3}\right]$,

$V$ - objętość cząstek suchego lodu $\mathrm{CO}_{2}\left[\mathrm{~mm}^{3}\right]$.

\section{Literatura}

[1] Borkowski P.: Basis of highpressure water-ice jet creation and application for surface treatment, Surface Treatment VI, WIT Press, Southempton, Boston 2003, pp. 85-95.

[2] Borkowski P., Borkowski J.: Basis of high-pressure water jet implementation for polymetallic concretions output from the ocean's bottom, Annual Set Environment Protection, 13 (2011) 65-82.

[3] Borkowski P., Borkowski J.: Unconventional method of poly-metallic concretions output from ocean's bottom. Unconventional and HydroJetting Technologies (ISSN 0239-7129), Koszalin 2009, pp. 31-42.

[4] Engelman H.E.: Vertical hydraulic lifting of large-size particles - A contribution to marine mining, The $10^{\text {th }}$ Annual Offshore Technology Conf. 1978. OTC 3173.

[5] Govier G.W. et al.: The flow of complex mixtures in pipes, Van Nastrand Reinhold Co., New York 1972.

[6] Jędrysek M.O.: Deep-ocean exploration of metals ore deposits controlled by the international seabed authority: Selected aspects of the present state and possible mining, [in:] 21st WMC \& Expo 2008, Sobczyk \& Kicki (eds.), 2008 Taylor \& Francis Group, London 2008, ISBN 978-0-415-48667, pp. 325-328.

[7] Jedrysek M.O.: Polska w działalności Międzynarodowej Organizacji Dna Morskiego ONZ (interview), Przegląd Geologiczny, 55 (2007) 619-622. 
[8] Kotliński R.: Wyniki badań geologiczno-poszukiwawczych złóż konkrecji polimetalicznych w strefie Klarion-Klipperton na Oceanie Spokojnym, Przegląd Geologiczny, 40 (1992) 253-260.

[9] Oedjoe D. et al.: The pressure drop in the hydraulic lifting of dense slurries of large solid with wide size distribution, Trans. Institute of Chemical Eng., 1966, vol. 44.

[10] Proceedings of the Fourth Isope Ocean Mining Symposium, Szczecin 2001.

[11] Saito T. et al.: Dimensionless flow characteristics on air lift pump, 3 (1991) 27-36.

[12] Tindcheng L., Jiling M., Sheng L., Chengliang X.: Simulative analysis for deep seabed mining lifting systems. Int. Symp. New Applications of Water Jet Technology, Jsinomaki 1999, Paper No. H-3, pp. 245-254.

\section{BASIS OF HIGH-PRESSURE WATER-ICE JET IMPLEMENTATION FOR POLYMETALLIC CONCRETIONS OUTPUT FROM THE OCEAN'S BOTTOM}

\section{S u m m a r y}

The paper presents characteristics of polymetallic concretions deposited on the bottom of the ocean and their resources as well as areas of deposition, especially in the Clarion-Clipperton area, the Pacific zone of Polish concession. The concept of high-pressure waterjet implementation, supported with physical influence of $\mathrm{CO}_{2}$ dry ice pellets for concretions' output is presented. A very useful feature of ice used in the process that causes relatively neglected effect of clumping in the water environment is pointed out. Moreover, $\mathrm{CO}_{2}$ pellets, undergoing mechanical impact occurred in the machining zone, sublimate violently. The volume of $\mathrm{CO}_{2}$ gas bubbles at the bottom of the ocean is very small. The largest ones are 1.7 up to $2.1 \mathrm{~mm}$ in diameter. However, the huge number of those bubbles causes that the work area undergoes aggressive erosion similar to cavitation effect. The basis of concretions' hydro-pneumatic transportation from the ocean bottom is given too, pointing out the issue of air pressure inlet depth to the main transportation tube, in order to achieve proper efficiency. The flow structures in respective cross-sections of the tube, as well as theoretical analysis of the problem are also characterized in this paper.

Presented relations allow to choose important parameters, deciding about a quality of the developed method. Finally, the theoretical basis presented in this paper, based on erosive properties of high-pressure water-ice $\left(\mathrm{CO}_{2}\right)$ jet technique of exploitation should essentially contribute to an increase in the efficiency of poly-metallic concretions output.

Keywords: polymetallic concretions, high-pressure water-ice jet, $\mathrm{CO}_{2}$ dry ice, hydro-pneumatic transportation

DOI: $10.7862 / \mathrm{rm} .2017 .39$

Przestano do redakcji: 14.08 .2017

Przyjęto do druku: 18.10 .2017 
